\title{
胃癌手術時の輸血と予後との関係
}

\author{
菊 地 金男正宗良知 \\ 国立仙台病院外科
}

（昭和62年 4 月 11 日受付）

\section{RELATION BETWEEN PERIOPERAITVE BLOOD TRANSFUSION AND PROGNOSIS AFTER SURGERY FOR GASTRIC CANCER}

\author{
Kaneo Kikuchi and Ryochi Masamune \\ Department of Surgery, Sendai National Hospital
}

\begin{abstract}
Relation between perioperative blood transfusion and prognosis after surgery for gastric cancer was studied retrospectively on 2086 patients who had undergone histologically curative operation in the 2nd study of Cooperative Study Group of Surgical Adjuvant Chemotherapy for Gastric Cancer. These patients were divided into the 3 groups according to the administraiton of anticancer drugs (A: MMC, B: MMC + FT, C: FT). The survival and recurrence rate of transfused patients were compared with those of non-transfused patients in each histological stage of A, B and C groups.

Macroscopic factors of recurrence such as lymph nodal metastases, tumor size and serosal invasion in transfused patients were overestimated, and total gastrectomy with splenectomy and wide extirpation of lymph nodes were performed along with blood transfusion. But microscopic factors of recurrence in transfused patients were better than in non-transfused patients.

Five-year actuarial survival rate in transfused patients was generally lower than in nontransfused patients. Especialy the 5-year survival rates of transfused patients in stage II of A, C groups and stage III of A, B groups were respectively lower than those of non-transfused patients. Five-year actuarial recurrence rate in transfused patients was higher than in non-transfused patients. The 5 -year recurrence rates of transfused patients in stage I of A, B groups, stage II of A group and stage III of $B$ group were severally higher than those of non-transfused patients. Those rates were statistically significant.
\end{abstract}

\section{まえがき}

近年に打ける癌疾患に対する払大根治手術の向 上は, 麻酔の発達, 抗生物質の開発とともに輸血, 輸液の進歩に負らことろが少なくない。一方, 輸 血の晚期副作用として早くから輸血後肝炎が挙げ られ，現在な打非 A 非 B 型肝炎の対策に苦慮し ていることは周知の通りであるが，1973年 Opelz ら゙が腎移植に及ぼす輸血の影響について報告し て以来, 輸血の免疫抑制効果が俄かに注目されて 来た.

最近米国のみならず，わが国においても癌疾患 の術後生存率は輸血例が低率であるとの報告2) 7) が散見され，その要因としていずれる癌患者の輸 血による免疫機能の低下を示唆している。よって
著者らは, 手術時輸血施行率の高い胃癌を対象に, 輸血の有無と予後との相関関係を検索したので報 告する。

\section{I. 検索対象症例}

著者が関与している胃癌手術の補助化学療法研 究会（代表世話人井口潔, 以下胃手化研) が, 第 2 次研究として昭和 52 年から 54 年までの 2 年間 に, 全国の大学病院, 主要病院344施設の協力を得 て集積した症例中, 胃癌取扱い規約（第 9 版）に より組織学的に治癒切除と判定された症例で, 手 術死を除く2,086例を検索対象とした.これらの症 例に行った補助化学療法は, 封筒法により無作為 に割付けられ，A 群が Mitomycin-Cを手術日20 $\mathrm{mg}$, 翌日10mg one shot 静注するもので, B 群は 
A 群投与法に加光, Futraful(以下 FT) $600 \mathrm{mg}$ 連 日経口的に 1 年間投与する併用療法であり，C 群 の投与法はFT 600 $\mathrm{mg}$ の連日経口単独投与であ る ${ }^{8)}$.な打各群の症例教は, $\mathrm{A}$ 群668例, $\mathrm{B}$ 群689例, $\mathrm{C}$ 群729例である.

\section{II. 検索方法}

検索症例の各群を retrospective に組織学的進 行度 (st) 別に分け, 更に輸血例と非輸血例とに細 分し，それぞれについて Cutler-Ederer の生命表 法を用い, 累積生存率並びに累積再発率を算出し, generalized Wilcoxon testにより検定した。

\section{III. 検索症例の背景因子（表 1)}

各 st の各群別に予後を支配する背景因子につ いて輸血の有無別に比較し，カイ 2 乗検定を用い てその均一性を検討した。輸血例は, st II B 群に 男性が多く, 占居部位についてみれば, st I C 群, st II の B，C群， st III の A， B 群に噴門部癌が 多く，有意差が認められた。 また st II の各群とも 輸血例に浆膜浸潤ありと判断された例が多く, st IV の B，C 群も同様の傾向があり，またりンパ節 転移も高度と見做された例が多かった。すなわち 輸血例は, 切除範囲も広く, 合併切除も少なくな く, 郭清度も大であった。しかしながら組織学的 にみれば, st II の B 群の輸血例に $\operatorname{ss} \beta$ が有意に多 くみられたに過ぎない。各群の st 毎に, 輸血の有 無別に絶対治癒切除の占める割合を検討してみる と，st 毎に若干の差はあるが，輸血例には広汎な 郭清例が多いために絶対治癒切除が多かった。
表 1 輸血の有無別による背景因子の均一性

\begin{tabular}{|c|c|c|c|c|c|c|c|c|c|c|c|c|}
\hline stage & \multicolumn{3}{|c|}{ I } & \multicolumn{3}{|c|}{ II } & \multicolumn{3}{|c|}{ III } & \multicolumn{3}{|c|}{ IV } \\
\hline 群 & A & B & $\mathrm{C}$ & A & B & $\mathrm{C}$ & A & B & $\mathrm{C}$ & A & B & $\mathrm{C}$ \\
\hline 性 & & & & & $*$ & & & & & & & \\
\hline 年料会 & & & & & & & & & & & & \\
\hline 占居 部 位 & & & $* *$ & & $*$ & ** & * & $*$ & & & & \\
\hline 大きさ & & & & & $*$ & & $*$ & & $*$ & & & \\
\hline 漿膜 浸 潤 & & & & ** & $* *$ & $* *$ & $*$ & & & & ** & $*$ \\
\hline $\mathrm{N}$-numb & & & & ** & $*$ & & * & $*$ & & & & \\
\hline 切除範囲 & ** & $*$ & $* *$ & ** & $* *$ & $* *$ & $* *$ & ** & & & $*$ & $*$ \\
\hline 合併切除 & & & $* *$ & $* *$ & $* *$ & $* *$ & $* *$ & $* *$ & & & $* *$ & \\
\hline 郭 清 度 & & & & $*$ & $* *$ & $*$ & & & & & & \\
\hline n-numb & & & & & & & & & & & & \\
\hline 深 達 度 & & & & & $*$ & & & & & & & \\
\hline 根 治 度 & & & & & & & & & & & & \\
\hline
\end{tabular}

\section{IV．検索成績}

1. 累積生存率

各 stに打ける各群の輸血の有無別にみた 5 年 生存率（以下 5 生率）を表 2 に示した。 st I C 群, st IV B 群の輸血例が非輸血例に比してやや高率 であった以外は, 各 st の各群とも輸血例の 5 生率 が全般に低値を示し，特にst III B 群においては 輸血例が有意に低率であり，また st II A，C 群， st III A 群では有意の傾向が認められた.

症例数の多いst I, II, III について各群の生存 曲線を輸血の有無別にみると，st I に打いてはA 群の輸血例が全経過を通して低率であるが，有意

表 2 〔胃手化研 2 次〕 5 年生存率(輸血の有無別)

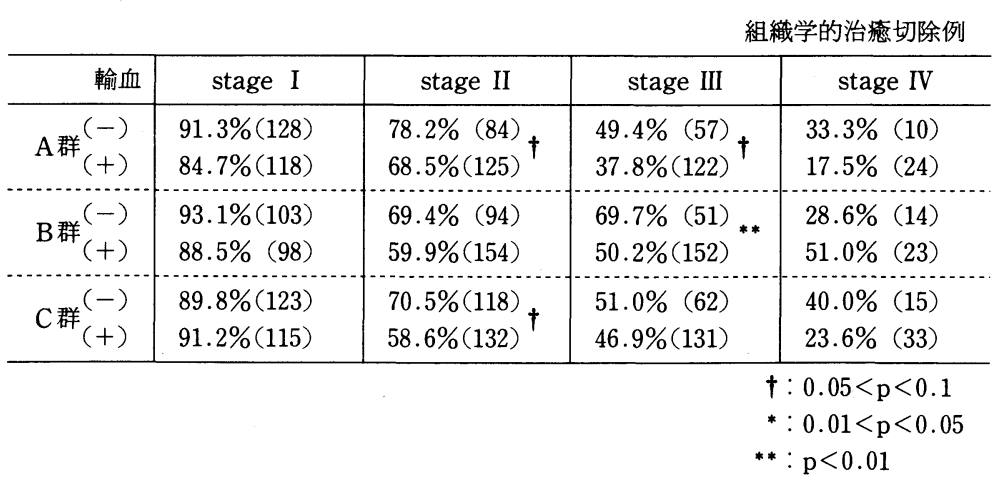


差はなく，また B, C 群では輸血による影響は全く なかった(図 1). st II では A，C群とも輸血例が 1 生率から低率であり，5生率ではそれぞれ $\mathrm{p}=$ 0.092，0.058で，有意の傾向がみられた。しかし $\mathrm{B}$ 群は術後 1 年半までは両者の間に差はなく, 2 年後から漸次輸血例が低下するが， 5 生率には有 意差がなかった（図 2). st III においてはA，B 群とも 1 年後から差が開きはじめ, 次第に大とな り, 5 生率は $\mathrm{A}$ 群で有意の傾向 $(\mathrm{p}=0.056), \mathrm{B}$ 群

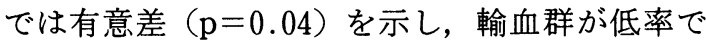
あった。しかし C 群には輸血の有無による差はな かった（図 3 ）.

\section{5 年累積再発率}

各 st の群別にみた輸血例と非輸血例との 5 年 累積再発率 (以下 5 再率) を表 3 に示した。 st IV $\mathrm{B}$ 群の輸血例が低率であるが，有意差はなく，そ れ以外の各 st の各群とも輸血例が高率であり, 特 にst I B 群, st III B 群では有意差 $(\mathrm{p}<0.05)$ が認められ, st I A 群, st II A 群には有意の傾向

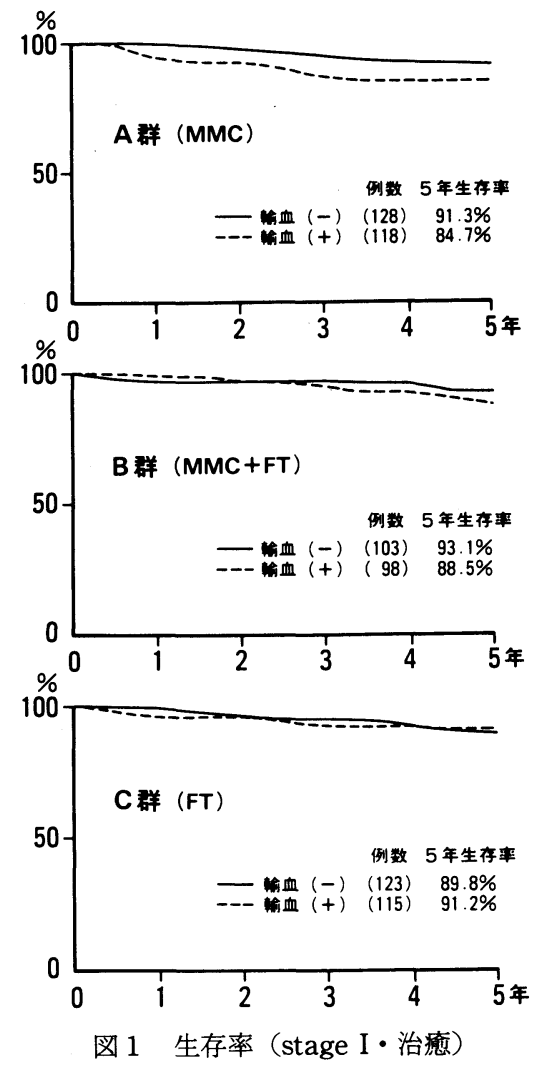

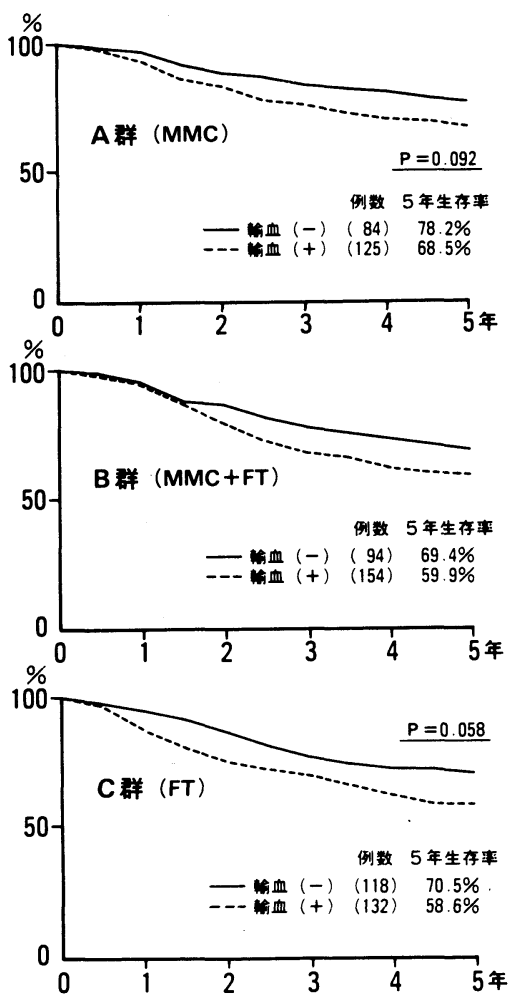

図 2 生存率 (stage II・治瘾)

\section{がみられた（表 3 ）。}

st I, II, III について累積再発曲線を画いてみる と, st I においては A 群の輸血例に 1 年以内の再 発がみられ，5年以内の再発総数の半数以上が 2 年以内に再発していた。 5 再率は輸血例 $17.1 \%$, 非輸血例10.3\%で，両者の間に有意の傾向が認め られた。 B 群では再発が遅く，特に非輸血例は輸 血例より 1 年遅く， 5 再率は輸血例 $12.4 \%$ ，非輸 血例が $5.0 \%$ で，両者の間に有意差がみられ，C群 も非輸血例の再発は遅延しているが， 5 再率に有 意差はなかった(図 4 ). st II の再発曲線は, 非輸 血例では緩やかに上昇するが，輸血例はやや急峻 な上昇を示し，A 群では両者の間に有意の傾向が みられたが, B，C 群では輸血例が低率を示すもの の有意差はなかった。各群とも st I 同様に， 2 年 以内の再発が 5 年以内再発総数の過半数を占めて いた（図 5 ). st III に打ける再発曲線は, st II 上 りも更に急峻となり, $\mathrm{A}$ 群の 2 年再発率は, 輸血 例 $50 \%$, 非輸血例が35\%の高率を示した。B 群で 


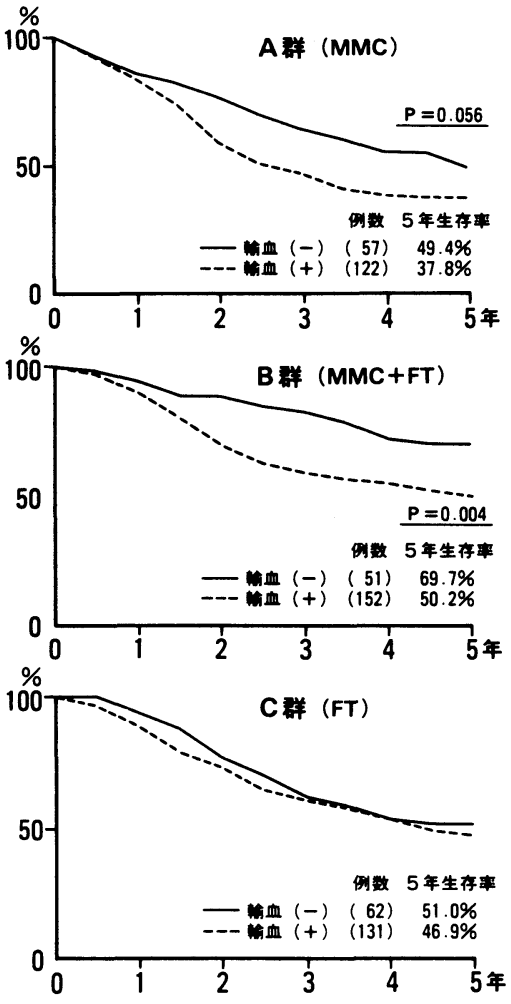

図 3 生存率（stage III・治瘏）
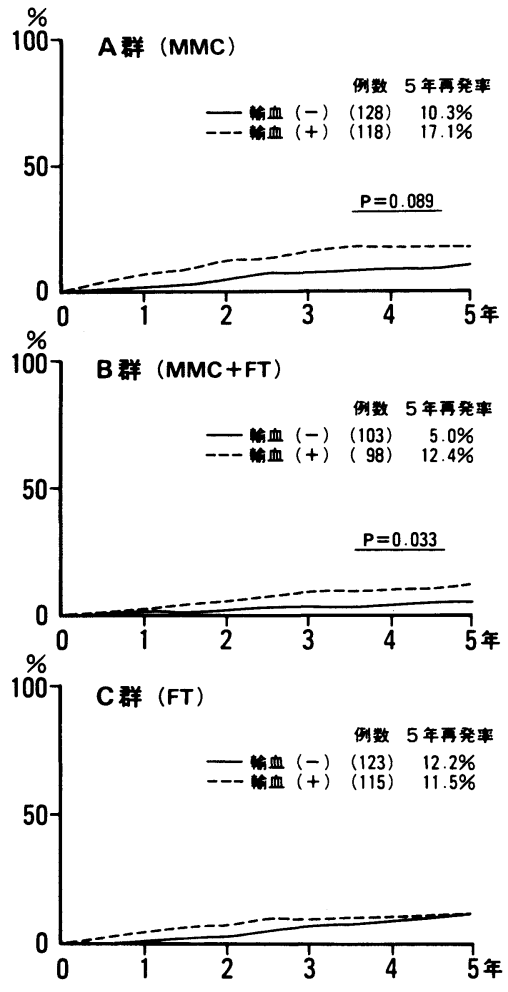

図 4 累積再発率 (stage I・治疾)

表 3 〔胃手化研 2 次〕 5 年累積再発率(輸血の有無別)

\begin{tabular}{|c|c|c|c|c|}
\hline \multicolumn{5}{|c|}{ 組織学的治瘾切除例 } \\
\hline 輸血 & stage I & stage II & stage III & stage IV \\
\hline A 群 ${ }_{(+)}^{(-)}$ & $\begin{array}{l}10.3 \%(128) \\
17.1 \%(118)\end{array} \dagger$ & $\begin{array}{l}23.0 \%(84) \\
34.0 \%(125)\end{array} \dagger$ & $\begin{array}{l}50.0 \%(57) \\
64.6 \%(122)\end{array}$ & $\begin{array}{l}77.6 \%(10) \\
85.4 \% \quad(24)\end{array}$ \\
\hline B群 ${ }_{(+)}^{(-)}$ & $\begin{array}{c}5.0 \%(103) \\
12.4 \% \text { (98) }\end{array}$ & $\begin{array}{l}35.7 \%(94) \\
42.3 \%(154)\end{array}$ & $\begin{array}{l}32.2 \%(51) \\
54.5 \%(152)\end{array}$ & $\begin{array}{l}71.4 \% \quad(14) \\
46.2 \% \quad(23)\end{array}$ \\
\hline C 群 ${ }_{(+)}^{(-)}$ & $\begin{array}{l}12.2 \%(123) \\
11.5 \%(115)\end{array}$ & $\begin{array}{l}32.9 \%(118) \\
39.8 \%(132)\end{array}$ & $\begin{array}{l}54.0 \%(62) \\
53.6 \%(131)\end{array}$ & $\begin{array}{l}68.0 \% \\
75.2 \% \quad(15)\end{array}$ \\
\hline & & & & $\begin{array}{l}0.05<\mathrm{p}<0.1 \\
0.01<\mathrm{p}<0.05 \\
\mathrm{p}<0.01\end{array}$ \\
\hline
\end{tabular}

は輸血例, 非輸血例とも $\mathrm{A}$ 群に比べて緩やかに上 昇するが，両者の差は $1 \sim 2$ 年に増大し，以後ほ ぼ平行して漸増し， 5 再発率には有意差が認めら れた。 C 群は, 輸血による羑はなく， A 群に類似 した曲線を画いた（図6）。

\section{V. 考案}

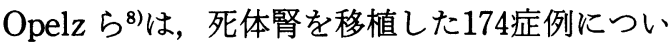

て予後調查を行い，手術前に反復して輸血を行っ た症例の腎生着率が非輸血例に比較して著しく高 率であったことを報告し，輸血が移植患者の免度 機能を抑制することを推論した。輸血が受血者の 免疫機能の低下を招くならば，輸血によって辧ら される癌患者の免疫抑制状態が，治療成績に多か れ少なかれ悪影響を及ぼすことが危惧される。 

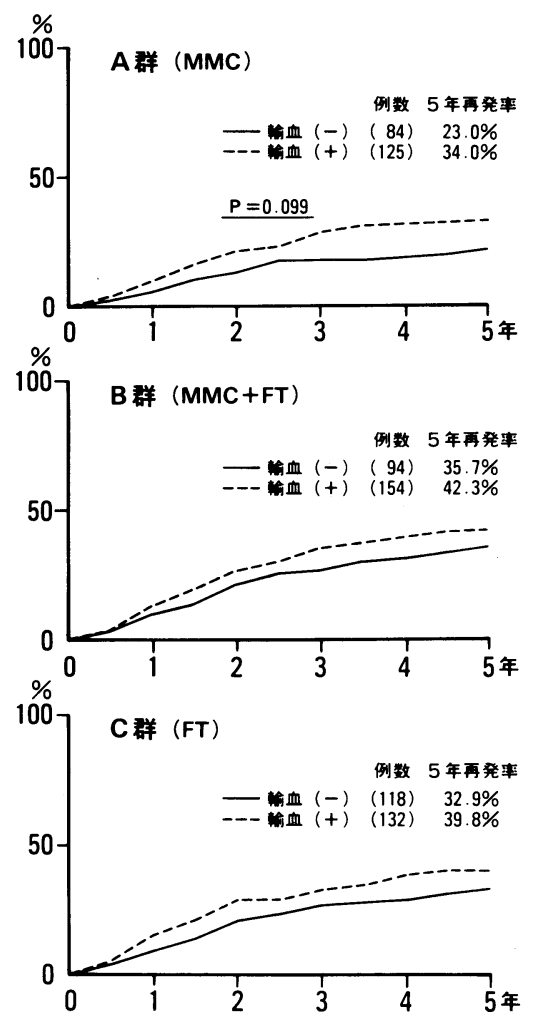

図 5 累積再発率 (stage II ・治癒)
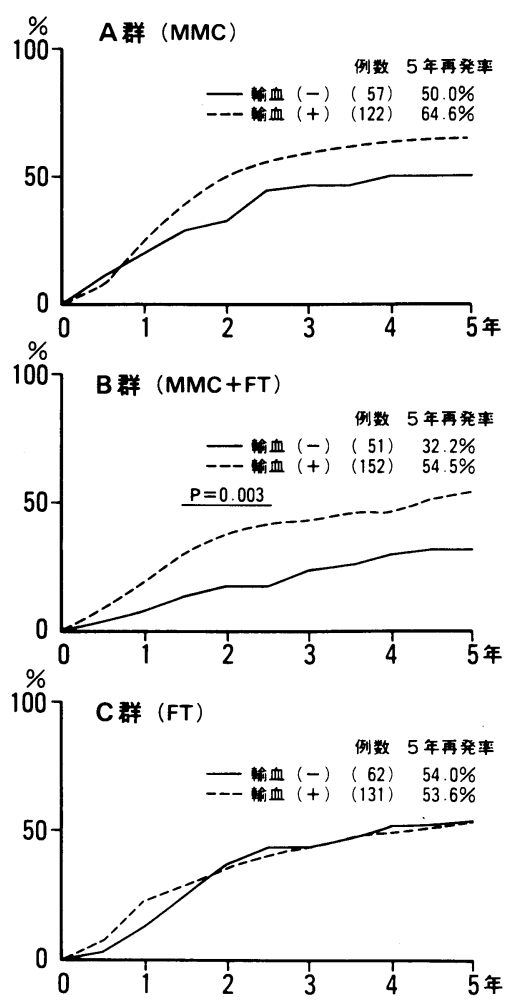

図 6 累積再発率 (stage III・治癒)
輸血による免疫抑制の作用機序については，未 だ解明されていないが，二宮ら ${ }^{99}$ は同種輸血によ り NK 活性が著しく低下することを実験的に立 証し, 担癌患者に対する輸血が癌治療成績の低下 を招く盧れのあることを警告している．Burrows $ら^{2)}$ は，大腸癌の手術前後の時期における輸血が 無再発生存率を著しく低下させることを報告し, 実験的に推論された輸血の免疫抑制効果が臨床的 に裏付けられたと述べている。 また Foster ら², Blumberg 5) も大腸癌の術後成績から Burrows らと同様の見解を示している。我が国においても 金田ら ${ }^{5)}$ は胃癌を対象に，また八木田ら ${ }^{6}$ 恄腸 癌, 乳癌について輸血と生存率との相関関係を検 討し，それぞれ輸血群が有意に低率であったとし， 輸血が癌患者の免疫抑制に重要な役割を演じてい ることを示唆している.

著者らの症例は，肉眼的にみれば輸血例と非輸 血例との間に背景因子にかなりの相違がみられ， 特に輸血例において占居部位が噴門側に多く, ま
たリンパ節転移, 浆膜浸潤も高度と判断されたた めに，切除範囲も広く，胃全摘出や脾摘出などの 合併切除が多く，リンパ節郭清度も大であった。 従って出血量も多く，輸血を行わざるを得なかっ たと思われる。しかしながら組織学的にみた背景 因子は st II B 群の輸血例に ss $\beta$ が多かった以外 は, 輸血の有無による差は全くなく, むしろ各群 とも st 別にみて輸血例に絶対治癒切除例が多 かった。脾摘出の予後に及ぼす影響については未 だ一定の見解はなく，5生率，5再率を左右する 因子としては考えなかった。

著者らの検索症例を各 st, 各群別にみて輸血例 は, st IV B 群においてのみ良好な成績を示した が，有意差はなく，症例数の多いst I III では全 般に非輸血例に比べて予後は不良であった。特に 5 生率では st II A, C 群, st III A， B 群，5再 率では st I A, B 群, st II A 群, st III B 群こ輸 血例と非輸血例との間に有意差ないし有意の傾向 がみられ，諸家の成績を肯定する結果を得た。著 
者らは, 対象例の免疫機能の追求を行っていない ので, 前述の成績がすべて輸血によるものとは断 定し得ないが, 今後受血者の免疫機能の変動を追 求するとともに, 癌手術時の輸血については十分 配慮すべきことを強調した。

$$
\text { むすび }
$$

胃手化研第 2 次研究の症例中, 組織学的治癒切 除2,086例を, 制癌剂投与法により 3 群に分け, 各 st 毎に輸血の生存率, 再発率に及ぼす影響を検討 した。輸血例と非輸血例との間には組織学的背景 因子に差はなかったが, 輸血例の生存率は全般に 低く, 再発率は高く, 統計学的差を示すものが少 なくなかった。

\section{文 献}

1) Opelz, G., Mickey, M.R., Terasaki, P.I., et al. : Effect of blood transfusion on subsequent kidney transplants. Transplant. Proc., $5: 253-259$, 1973.

2) Burrows, L. and Tartter, P.: Effect of blood transfusion on colonic malignancy recurrence rate. Lancet, II : 662, 1982.
3) Foster, R.S., Costanza, M.C., Foster, J.C., et al. : Adverse relationship between blood transfusion and survival after colectomy for colon cancer. Cancer, 55 : 1195-1201, 1985.

4) Blumberg, N., Agarwal, M.M. and Chuang, C. : Relation between recurrence of cancer of the colon and blood transfusion. Brit. M. J., 290 : 1037-1039, 1985.

5）金田道弘, 堀見忠司, 折田薰三, 他：胃癌生存率 に及ぼす輸血の効果. 外科, $48 ： 1061-1064,1986$.

6) 八木田旭邦, 竹内教能, 立川 勲, 他：結腸癌と 乳癌の根治術後の予後に与える輸血の影響. 医学 のあゆみ, $139 ： 119-120,1986$.

7）葛西洋一, 井口 潔, 菊池金男, 他：胃癌に対す るマイトマイシンC, フトラフール術後長期化学 療法の効果に関する研究一第 2 次研究一(第 1 報)。癌と化学療法, 9：1449-1460, 1982.

8) Opelz, G., Graver, B. and Terasaki, P.I. : Induction of high kidney graft survival rate by multiple transfusion. Lancet, I: 1223-1225, 1981.

9）二宮基樹, 堀見忠司, 折田薰三, 他：輸血の生体 に及ぼす影響一NK 活性よりみた考察。医学のあ ゆみ, $133: 609-610,1985$. 